\title{
New taxonomic status to the French Guianan Nectomys parvipes Petter (Rodentia, Sigmodontinae)
}

\author{
Cibele R. Bonvicino $^{1}$
}

\begin{abstract}
Morphological characters used for separating Nectomys parvipes Petter, 1979 from $N$. squamipes melanius Thomas, 1910 are the same used for separating Nectomys from the smaller taxon Sigmodontomys J.A. Allen, 1897. Principal Component analyses grouped $N$. parvipes holotype with $S$. alfari specimens and apart from $N$. s. melanius specimens. Both morphology and morphometry indicated that $N$. parvipes belongs to the genus Sigmodontomys.

KEY WORDS. Rodentia, Sigmodontinae, Nectomys, Sigmodontomys parvipes, taxonomy
\end{abstract}

In French Guiana, PETTER (1979) discovered a water rat sympatric with Nectomys squamipes melanius Thomas, 1910. He described this new rodent as Nectomys parvipes Petter, 1979, distinguishing it from N. s. melanius by a smaller body, hind foot, and third upper molars' size (Tab. I) as well as by the shape of the fronto-parietal suture and anterior border of the zygomatic plate. Characters used in Petter's description of $N$. parvipes, including illustrations of dental differences and morphometric comparisons, were practically the same as those used by HERSHKOVITZ (1944) for diagnosing the subgenus Sigmodontomys Allen, 1897. However, shape of fronto parietal suture and of anterior border of the zygomatic plate were variable and overlapping among Sigmodontomys and Nectomys specimens when examined at the Field Museum of Natural History and the United States Natural Museum.

Table I. Comparative measurements. $(X)$ mean, (SD) standard deviation, range, and (n) number of specimens of Sigmodontomys alfari and Nectomys squamipes melanius. The measurements of Nectomys parvipes holotype are from Petter's description.

\begin{tabular}{|c|c|c|c|c|c|c|c|c|}
\hline & \multirow{2}{*}{$\frac{\text { N. parvipes }}{\text { Holotype }}$} & \multicolumn{3}{|c|}{ S. alfari } & \multicolumn{4}{|c|}{ N. squamipes melanius } \\
\hline & & $x$ & SD & $n$ & $x$ & & SD & $n$ \\
\hline Head-body & 135.0 & $143.0 \pm 5.7$ & $135-152.0$ & 10 & $185.4 \pm$ & 20.4 & $162.0-213.0$ & 5 \\
\hline Tail & 152.0 & $169.6 \pm 6.6$ & $161-180.0$ & 9 & $195.0 \pm$ & 13.9 & $180.0-215.0$ & 5 \\
\hline Hind foot & 37.0 & $34.6 \pm 0.9$ & $33.5-36.5$ & 9 & $47.2 \pm$ & 4.9 & $38.0-51.0$ & 9 \\
\hline Ear & 17.0 & $19.8 \pm 1.5$ & $18.0-22.0$ & 5 & $22.8 \pm$ & 1.2 & $22.0-25.0$ & 6 \\
\hline Greatest skull length & ca 35.0 & $35.0 \pm 0.9$ & $33.6-35.9$ & 9 & $41.5 \pm$ & 3.0 & $37.2-43.2$ & 7 \\
\hline Zygomatic breadth & 19.2 & $18.6 \pm 0.5$ & $17.4-19.1$ & 9 & $21.3 \pm$ & 1.3 & $19.2-22.5$ & 6 \\
\hline Interorbit.constriction & 6.0 & $6.1 \pm 0.2$ & $5.9-6.4$ & 10 & $7.1 \pm$ & 0.3 & $6.5-7.4$ & 10 \\
\hline Upper molar row & 5.8 & $5.7 \pm 0.3$ & $4.9-6.0$ & 10 & $6.7 \pm$ & 0.3 & $6.2-7.1$ & 10 \\
\hline
\end{tabular}

The genus Sigmodontomys Allen, 1897 was considered a junior synonym of Nectomys (GYLDENSTOLPE 1932), a sub genus of Nectomys (HERSHKOVITZ 1944) or a subgenus of Oryzomys (GARDNER \& PATTON 1976), and again considered a

1) Serviço de Genética, Pesquisa Básica, Instituto Nacional de Câncer. Praça da Cruz Vermelha 23, 20230-130 Rio de Janeiro, Rio de Janeiro, Brasil. 
valid genus (MUSSER \& CARLETON 1993). However, these latter authors commented that its relationship with other sigmodontines rodents required investigations and, following earlier reports (NOWAK \& PARADISO 1983), treated parvipes as a species of Nectomys.

Two thousand and sixty five Nectomys and 115 Sigmodontomys specimens in the following Institutions were examinated: American Museum of Natural History (New York, 268 Nectomys), Field Museum of Natural History (Chicago, 333 Nectomys and 18 Sigmodontomys), United States National Museum (Washington, 323 Nectomys and 97 Sigmodontomys), Museu Nacional (Rio de Janeiro, 519 Nectomys), Museu de Zoologia da Universidade de São Paulo (São Paulo, 301 Nectomys), Museu Paraense Emílio Goeldi (Belém, 154 Nectomys), Universidade de Brasília (Brasília, 41 Nectomys), Universidade da Paraíba (João Pessoa, 49 Nectomys), and Universidade Federal do Rio Grande do Sul (Porto Alegre, 7 Nectomys). On the basis of these examinations, I agree that parvipes is a different species of water rat, though it should be transferred to the genus Sigmodontomys. In order to investigate the relationship of $N$. parvipes with Nectomys and Sigmodontomys I carried out morphological analyses using a sample of Sigmodontomys alfari, Nectomys squamipes melanius and the single known specimen of $N$. parvipes, the holotype. For Principal Components Analysis I exclusively considered adult animals (with all teeth erupted and functional) using natural logarithmic variables. Principal Components Analysis (Fig. 1) grouped N. parvipes with S. alfari apart from N. s. melanius. This separation occurred in the plane of the first principal component.

The resemblance noted by PETTER (1979) between the French Guianan $N$. parvipes and the geographically remote populations of Sigmodontomys sp. in Central America, Venezuela, and Colombia was considered to be a result of convergence. This postulation must have been based on the geographic discontinuity and distances separating Sigmodontomys sp. from Nectomys sp.. In view of the arguments herewith presented, PETTER's (1979) report provided the first records of Nectomys squamipes melanius and Sigmodontomys in French Guyana, thus extending the range of Sigmodontomys.

The genus Sigmodontomys can be diagnosed by its smaller body size than Nectomys, about the size of a moderate large Oryzomys, skull moderately large, robust, more heavily built than in Nectomys or any other oryzomyine rodent, supraorbital ridges lower and more projected than in Nectomys, incisive foramina proportionally lower than in Nectomys, cheek teeth proportionately larger with lower crests than in Nectomys, upper and lower second and third molars almost equally wide as long but distinctly longer than wider in Nectomys, upper and lower third molar significantly smaller than in Nectomys; upper $\mathrm{M}^{3} \mathrm{M}^{3}$ distance smaller than upper $\mathrm{M}^{1} \mathrm{M}^{1}$ distance against same upper $\mathrm{M}^{3} \mathrm{M}^{3}$ and $\mathrm{M}^{1} \mathrm{M}^{1}$ distances in Nectomys; first $\mathrm{M}^{1}$ fold (on labial side) interrupted in Sigmodontomys and continuous in Nectomys.

It is therefore concluded that Nectomys parvipes is a member of a genus of smaller body size and should be named Sigmodontomys parvipes, comb.n.. 


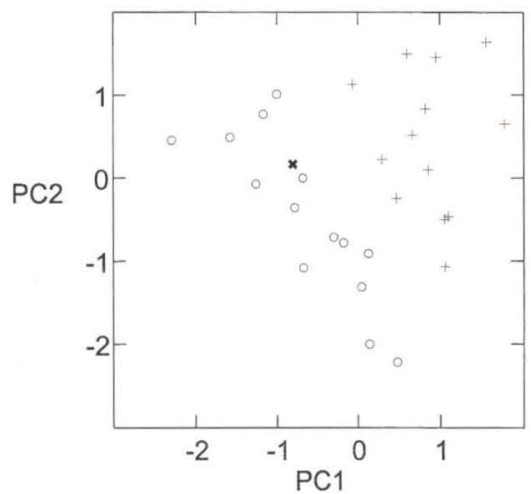

Fig. 1. Scores of the first two principal components (PC). Nectomys squamipes melanius (+), Nectomys parvipes holotype $(\mathrm{X})$ and Sigmodontomys alfari $(\mathrm{O})$. The eigenvalues of the first two principal components are 2.954 (PC1) and 0.676 (PC2), corresponding to $73.8 \%$ and $16.9 \%$ of total variance.

ACKNOWLEDGMENTS. I am grateful to P. Hershkovitz and H. Seuánez for reviewing previous version of the manuscript and for valuable suggestions to $\mathrm{R}$. Cerqueira for laboratories facilities and to B. Lemos for help in morphometric analyses. I am grateful from the following persons for allowing to study specimens: L. Flamarion (Museu Nacional, Rio de Janeiro), A. Langguth (Universidade Federal da Paraíba, João Pessoa), J. Marinho (Universidade de Brasília), M. Mattevi (Universidade Federal do Rio Grande do Sul, Porto Alegre), S. Marques (Museu Paraense Emílio Goeldi, Belém), P. Hershkovitz (Field Museum of Natural History, Chicago), G. Musser (Americam Museum of Natural History, New York), and M. Carleton (United States National Museum, Washington). Work supported by CNPq, Barbara Brown Foundation, Smithsonian Institution, INCa.

\section{REFERENCES}

Allen, J.A. 1897. Additional Notes on Costa Rica Mammals, with descriptions of new species. Bull. Amer. Mus. Nat. Hist. 9: 31-44.

GARDNER, A.L. \& J.L. PATTON. 1976. Karyotype variation in oryzomyine rodents (Cricetinae) with comments on chromosomal evolution in the neotropical cricetine complex. Occ. Pap. Mus. Zool. 49: 1-48.

GYLDENSTOLPE, N.C.G. 1932. A manual of Neotropical rodent sigmodont rodents. Kungl. Svenka Vetenskapsakad. Handl., ser. 3, 11 (3): 1-164.

HershKovitz, P. 1944. A Systematic review of the Neotropical water rats of the genus Nectomys (Cricetinae). Misc. Publ. Mus. Zool. Univ. Michigan 58: $1-101$.

Musser, G. \& M.D. Carleton. 1993. Family Muridae, p.501-755. In: D.E. Wilson \& D.M. REEDER (Eds). Mammal Species of the World. Cidade, Smithsonian Institution Press, $2^{\text {nd }}$ ed., 1209p.

NOWAK, R.M. \& J.L. PARADISO. 1983. Walker's mammals of the world. Baltimore, Johns Hopkins University Press, 4th ed., Vol. 2, p.569-1362.

PetTER, F. 1979. Une nouvelle espèce de rat d'eau de Guyane française, Nectomys parvipes sp. nov. (Rongeurs, Cricetidae). Mammalia 43: 507-510.

Recebido em 04.VI.1998; aceito em 16.XI.1999. 